\title{
Effects of Planting Date on Winter Canola Growth and Yield in the Southwestern U.S.
}

\author{
Sultan H. Begna, Sangamesh V. Angadi \\ New Mexico State University, Agricultural Science Center, Clovis, NM, USA \\ Email: sbegna@nmsu.edu
}

Received 4 December 2015; accepted 25 January 2016; published 28 January 2016

Copyright (C) 2016 by authors and Scientific Research Publishing Inc.

This work is licensed under the Creative Commons Attribution International License (CC BY). http://creativecommons.org/licenses/by/4.0/

(c) (i) Open Access

\begin{abstract}
Canola (Brassica napus L.) has potential to become alternative cash crop (healthy oil for human and meals for animal uses) with tremendous rotational benefits in the Southwestern U.S., a region dominated by cereal-fallow cropping systems. However, information on optimum planting date for its successful production is limited. Field experiments were conducted in 2011-12 and 2012-13 seasons under irrigation condition to study the response of canola growth and yield to planting dates at Clovis, NM. Three planting dates (mid-September, late-September and early-October) and four canola varieties (early flowering: DKW41-10 and DKW46-15; medium flowering: Riley and Wichita) are studied. Fall plant stand density is significantly higher for early-October than midand late-September plantings. However, a ratio of fall to spring plant stand density indicates a greater reduction in spring plant stand density with early-October (25\%) and mid-September (19\%) than late-September (7\%). Vegetative (by 13 days) and flowering (by 7 days) duration phases are significantly shortened with delay in planting. The decline in aboveground dry matter (DM) due to delayed planting resulted in significant seed yield reduction in both 2011-12 (26\%) and in 2012-13 (8\%) when early-October and mid-September plantings were compared. There was a positive relationship between final DM and canola seed yield, accounting for 84 and $34 \%$ variation for 2011-12 and 2012-13 seasons, respectively with the 2011-12 environmental conditions being conducive for genetically controlled variation in DM production to be more apparent and strong in explaining the variation in seed yield among varieties. Medium-flowering varieties

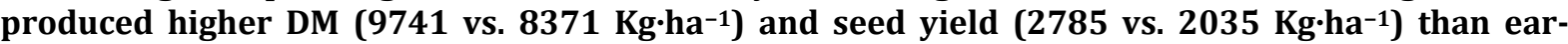
ly-flowering varieties. In addition to seed yield, DM can be used as an indirect selection criterion for seed yield in variety selection and appropriate planting dates including a guarantee for high crop residues ( $\sim 75 \%$ of the total aboveground biomass) production to make canola a potential alternative cash and rotational break crop in the Southwestern U.S.
\end{abstract}

\section{Keywords}

Alternative Potential Crop, Planting Dates, Yield, Diversity, Southwestern U.S. 


\section{Introduction}

Canola has become the second largest oil crop after soybean in the world in just two decades [1] [2]. Recent rapid increase in production is associated with increases in demand for oil (as healthy oil for human use) and meal for animal feed [3]. USA's share of the world canola production was still small (spring and winter canola combined with 0.655 and 1.002 million tons in 2008 and in 2013, respectively) but had increased substantially. Canola's benefits as a good break/rotational crop are also another factor for the increase in canola production in a region with cereal-fallow or continuous cereal based cropping systems [4]-[8]. Grower's interest in winter canola in the Southern Great Plains of the USA is increasing in part to the benefits mentioned above and the crop's good fit to the growing conditions and cropping systems of the region. Winter canola production area has increased from about 20,000 in 2009 to over 73,000 ha in 2012 in the Southern Great Plains [8]. Moreover, the value of canola's meal after oil extraction from seed crushing is potential protein rich animals feed for the large dairy and beef industries that exist in west Texas and eastern New Mexico. Thus, there is a market for growers to sell their seeds to a crushing company easily since seed crushing plants are available in the region. However, there is limited information on optimum planting date for winter canola in this region, the Southwestern U.S. in particular.

Planting date is one of the most important and manageable agronomic practices that affect growth, dry matter production, quality and yield of crops [9]-[16]. With other plant growth affecting factors being unlimiting, early planting has been generally found to improve crop growth and yield compared to late planting of both spring and winter type crops. Unlike spring crops, winter crops have to overwinter and appropriate planting date is even more crucial for the crops to establish well in the fall and overwinter and resume growth in spring and make economical yield. Finding winter survival canola varieties for the region has been a challenge but progress has been made by breeders of both public and private organizations with the development of varieties that are winter tolerant and yields comparable to other winter canola growing areas of the world [8]. New Mexico, as part of the Southwestern U.S., is one of the states where the national winter canola variety test is being conducted and its winter survival and yield potentials being documented [17].

The planting window for canola in the Southern Great Plains is wide ranging from mid-August to mid-October. Planting too early can lead to large plants resulting in excessive water and nutrient use while too late planting can produce small plants that are prone to winter kill [15] [16]. For canola seed to emerge and have two unfolded leaves, it will require about 218-324 growing degree days [18] which can be achieved with even earlyOctober planting in the Southwestern U.S. Unlike spring crops, however, good emergence in winter crops is not a guarantee for final good plant stand since final plant stand is determined by spring not by fall plant stand, and this in turn can be affected by weather and cultural practices including planting date. It was reported that later planting date (October 15) for canola in Kansas produced higher fall plant stand than mid-August, early-, midand late-September plantings in one of two years studies. In this study, spring plant stand was reported to be not different among the earlier planting dates, however later planting dates (late-September and mid-October) despite having higher fall plant stand, plants did not survive the winter [15]. A study done in China showed that winter extreme low temperatures resulting from late plantings (passed early-October) damaged established canola leading to significant yield reduction [16]. A study done in Australia on canola and mustard showed that a yield potential of early planting over later planting if plants of early plantings are not affected by spring frost damage during flowering and grain filling [13]. Generally, vegetative growth and maturation periods are affected by planting date leading to dry matter production and yield difference between early and late planting dates.

Several researchers have reported a positive relationship between dry matter production (both at flowering and maturity) and seed yield of many crops including canola, with the higher the dry matter the higher the seed yield which, in turn, can be affected by planting dates [9]-[14] [16] [19] [20]. A biomass of $5000 \mathrm{Kg} \cdot \mathrm{ha}^{-1}$ at flowering has been suggested for canola as maximum enough for maximum yield with little yield advantage for crops with higher levels of biomass [21] [22]. However, several studies done in different parts of the world showed an increase in seed yield with an increase with biomass both at flowering and maturity [13] [16] [20] [23]. A study done in Australia [19] using measured data and a simulation model reported a 3\% to 9\% canola seed yield reduction per week of planting date delay for the high and low rain regions, respectively. A study done in China using method mentioned above reported a yield penalty due to delayed planting (passed early-October) by as much as $20 \%$ [16]. A study done in Kansas showed that seed yield reduction by $18 \%$ with 
mid-September and mid-August compared to early-September plantings. The Kansas research, canola planted after September 15 did not consistently survive winter resulting in no seed production [15]. In the Southeastern U.S. where winter is milder than the above mentioned regions, canola seed yield was significantly reduced with mid- and late-October planting compared to early-October planting [24]. On the other hand, oil content was reported to be positively related to harvest index and seed size and negatively to temperature conditions post-anthesis [13] [16]. The economy of winter oilseed rape cultivation is determined primarily by the achievable seed yield and less by oil content [25]. The biological yield of winter oilseed rape is the product of growth rate, duration of vegetative period, and seed filling [26] [27] which, in turn, can be affected by genetic, environmental, agronomic factors and the interaction between them [28]-[31]. Planting date is one of the most important and manageable agronomic factors that can affect crop production including canola. However, there is limited information on optimum planting date for successful winter canola production and hence an increase in production areas in the Southwestern U.S. The objective of this study was to investigate the response of growth and yield of canola to planting dates under Southwestern U.S. growing conditions.

\section{Materials and Methods}

\subsection{Experimental Site and Design}

The study was conducted during the 2011-12 and 2012-13 growing seasons at the New Mexico State University Agricultural Science Center at Clovis $\left(34.60^{\circ} \mathrm{N}, 103.22^{\circ} \mathrm{W}\right.$, elevation $\left.1331 \mathrm{~m}\right)$. Soil type was Olton clay loam (Fine, mixed, superactive, thermic aridic paleustolls). Soil test resulted in $29.1 \mathrm{ppm} \mathrm{N}, 32.8 \mathrm{ppm} \mathrm{P}$ and $606 \mathrm{ppm}$ K with pH of 7.5 and organic matter of 1.4\% in 2011-12 and $28.9 \mathrm{ppm} \mathrm{N}, 16.7 \mathrm{ppm} \mathrm{P}$ and $456 \mathrm{ppm}$ with pH of 7.5 and organic matter of $1.9 \%$ in 2012-13 growing seasons. Fertilizer was pre-plant soil incorporated (100.8-039.2-15.9 and 78.4-0-28.0-12.7 Kg.ha ${ }^{-1} \mathrm{~N}_{-} \mathrm{P}_{2} \mathrm{O}_{5}-\mathrm{K}_{2} \mathrm{O}-\mathrm{S}$ for 2011 and 2012, respectively) based on soil test results. The previous crop for both growing seasons was corn. In both years, herbicide Treflan (trifluralin) at the rate of $2.4 \mathrm{~L} \cdot \mathrm{ha}^{-1}$ was soil incorporated before planting for weed control. Hand-hoeing was also done as needed. Insecticide Intrepid (methoaxyfenozide and propylene glycol) at16.8 $\mathrm{L} \cdot \mathrm{ha}^{-1}$ and Corgan (chlorantraniliprole) at $350 \mathrm{~mL} \cdot \mathrm{ha}^{-1}$ were applied in spring to control insects, diamondback moth (Plutella xylostella) in particular in 2011-12 season. In 2012-13 season insecticides mixture of Dimethoate at $1.4 \mathrm{~L} \cdot \mathrm{ha}^{-1}$ and Acephoate, and Lannate (methomyl) at $4.2 \mathrm{~L} \cdot \mathrm{ha}^{-1}$ targeting flee beetle (Phyllotreta spp.) in particular and a mixture of Baythroid (beta-Cyfluthrin and cyclohexanone) at $196 \mathrm{~mL} \cdot \mathrm{ha}^{-1}$, and Prevathon (chlorantraniliprole) at $980 \mathrm{~mL} \cdot \mathrm{ha}^{-1}$ targeting harlequin bugs (Murgantia histrionica), flee beetle, lygus bugs (Lygus spp.) and moth larvae in fall and Trimax (imidacloprid) at $350 \mathrm{~mL} \cdot \mathrm{ha}^{-1}$ targeting false chinch bugs (Nysius raphanus), green peach aphid (Myzus persicae), cabbage aphid (Brevicoryne brassicae) and harlequins in particular were applied in late spring and a mixture of Dimethoate at $1.4 \mathrm{~L} \cdot \mathrm{ha}^{-1}$, Brigade (bifenthrin) at $420 \mathrm{~mL} \cdot \mathrm{ha}^{-1}$ and Brinstar at $5.6 \mathrm{~L} \cdot \mathrm{ha}^{-1}$ targeting harlequins, lygus bugs was applied in June of 2012-13 growing season. The application rates of herbicide and insecticides were determined based on the recommendation for weed and insect control indicated in the Great Plains canola production handbook.

In both years, canola was planted into a conventionally tilled seedbed under sprinkler irrigations. The row spacing was $0.15 \mathrm{~m}$ with a plot having 11 rows. Plot size was 9.14 by $1.68 \mathrm{~m}$. Canola was planted with a plot drill (Model 3P600, Great Plains Drill) at seeding rate of $6.7 \mathrm{Kg} \cdot \mathrm{Ka}^{-1}$ in both years and this is within the recommended seeding rate for canola production in this region. The experimental design was a randomized complete block with split plot arrangement replicated four times. The main plots had three planting dates (September 19 as mid-September, September 28 as late-September and October 7 as early-October). The subplots were 4 canola varieties (early flowering/maturing: DKW 41-10, DKW 46-15 and medium flowering/maturing: Riley and Wichita). The canola varieties were selected based on yield potential, flowering/maturity groups and seed availability. The early flowering/maturing (open pollinated and Roundup Ready) varieties were from Monsanto while the medium flowering/maturing (open pollinated) varieties were from Kansas State University.

Growing season weather data were collected from a National Weather Service station located at the Agricultural Science Center at Clovis. Sprinkler irrigations were applied as needed throughout the growing season and more so from the time the crop started regrowth in spring (Figure 1). In April and early May of 2012-13 crops were irrigated more to encourage more regrowth so that the damage caused by the unusual repeated freeze occurred that year could be compensated. Precipitation was not adequate in both growing seasons (with total precipitation from planting to final harvest was only 215 and 193 mm for 2011-12 and 2012-13 growing seasons, 


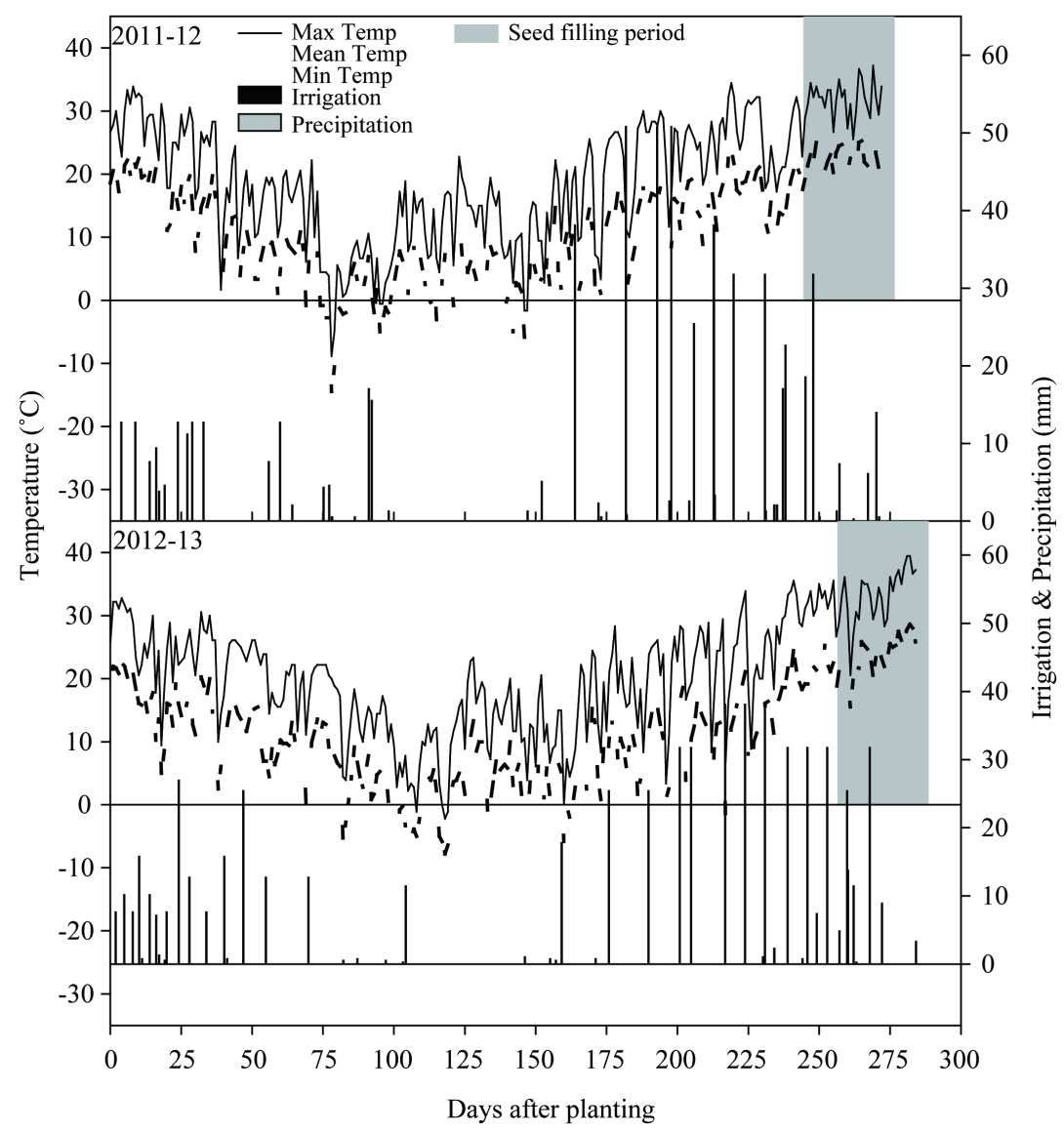

Figure 1. Daily minimum, mean and maximum temperature and daily irrigation and precipitation during 2011-12 and 2012-13 growing seasons.

respectively) resulting in 453.4 and $518.2 \mathrm{~mm}$ of irrigation water used in 2011-12 and 2012-13 seasons, respectively. Irrigation was terminated on May 26 and June 14, respectively, in 2011-12 and 2012-13 growing seasons. Daily irrigation and precipitation amounts along with daily minimum, maximum and mean temperature are presented in Figure 1.

\subsection{Data Collection}

Plots were assessed for fall and spring plant stand 2 rows of 1 meter taken from the center rows and converted into plant stand $\mathrm{m}^{-2}$. A fall to spring plant stand ratio was also calculated which is a good indicator of winter survival. When there was $50 \%$ of the plants in the plot with 1 flower or more the date was noted as bloom date. In 2012 the bloom date occurred between March 24 through April 4, 2012 and while in 2013 because of cooler temperatures it occurred between April 4 through 21, 2013. In 2013 there was a repeated freeze (Figure 1) resulting in plant parts being damaged including flower parts, buds and small pods leading to a regrowth and re-bloom of plants. In the 2012-13 season, beside the above parameters, vegetative growth was assessed on samples harvested $2.5 \mathrm{~cm}$ aboveground within $0.25 \mathrm{~m}^{2}$ area of each plots three times during the growing season. All plant samples were bagged and dried to a constant weight at $65^{\circ} \mathrm{C}$ to calculate the aboveground dry matter. Final harvest at $2.5 \mathrm{~cm}$ aboveground within $2 \mathrm{~m}^{2}$ of each plots were done on June 18 and July 2 for 2012 and 2013 seasons, respectively. Bagged plants samples were dried to a constant weight at $65^{\circ} \mathrm{C}$. Once total weight of each sample was recorded, samples were threshed with a plot combine (Model Elite Plot 2001, Wintersteiger, Ried, Austria) and seed were collected and weighed. Harvest index, the ratio of grain to total biomass (grain plus aboveground dry matter) was calculated for each plot. Seed oil content was also determined on seed samples sent to the Brassica Breeding and Research Lab at the University of Idaho and this also allowed calculation of oil yield (Oil yield, seed yield multiplied by seed oil content). 


\subsection{Statistical Analysis}

Statistical analyses were performed using SAS PROC MIXED procedures in SAS 9.3 [32] to detect if differences existed between planting dates and varieties and their interactions with year. Significance was considered at $p<0.05$ and protected LSD was obtained using the PDIFF statement in the LSMEANS option within SAS PROC MIXED to decide where differences occurred within significant interactions [33]. Regression functions were also fitted to the data and planting date of each growing season.

\section{Results and Discussion}

\subsection{Environmental Conditions}

The distribution of precipitation during the experimental periods varied between the years. Precipitation received during crop establishment and early plant growth stage (September through November) in the 2011-12 season ( 5 rain events with only one above $10 \mathrm{~mm}$ ) was lower than the 2012-13 season (8 rain events with three above $10 \mathrm{~mm}$ ). The opposite occurred during the later plant growth stage, especially during the month of March, April and May the time the crop is most active with flowering and podding process ( 9 rain events with two above $10 \mathrm{~mm}$ and 4 rain events with all below $10 \mathrm{~mm}$, for the 2011-12 and 2012-13 seasons, respectively) (Figure 1). The number of rain events and amounts during seed filling in 2011-12 and 2012-13 seasons were similar (8 and 6 rain events for 2011-12 and 2012-13 seasons, respectively with 2 of them above $10 \mathrm{~mm}$ ) and the growing period in both seasons can be considered as dry since the benefit from such rainfall events to the plants was limited. Total precipitation amount received during the 2011-12 $(215 \mathrm{~mm})$ and the 2012-13 $(193 \mathrm{~mm})$ growing seasons were similar (a difference of only $22 \mathrm{~mm}$ ) but still not enough to grow a crop with only precipitation. Thus, this study was done under limited irrigation and 104 and $137 \mathrm{~mm}$ of irrigation water was applied for 2011-12 and 2012-13 growing seasons, respectively, during the early growth stage "emergence through roseate" (September through November). Irrigation amount applied during the latter active part of the growing seasons (flowering and seed filling periods) were 279 and $32 \mathrm{~mm}$ in 2011-12 and 241 and $89 \mathrm{~mm}$ in 2012-13 seasons (Figure 1).

Temperature pattern during the crop cycle varied between the 2011-12 and 2012-13 seasons. Daily temperature ranged from $-8^{\circ} \mathrm{C}$ to $34^{\circ} \mathrm{C}$ (early growth stage), from $-9^{\circ} \mathrm{C}\left(12\right.$ minimum temperature events with below $0^{\circ} \mathrm{C}$ ) to $27^{\circ} \mathrm{C}$ (beginning of regrowth to beginning of flowering), from $-8^{\circ} \mathrm{C}$ ( 6 minimum temperature events with below $0^{\circ} \mathrm{C}$, flowering and podding stages) to $34^{\circ} \mathrm{C}$ (with 37 maximum temperature events above $21^{\circ} \mathrm{C}$ ), ranged from $9^{\circ} \mathrm{C}$ to $37^{\circ} \mathrm{C}$ (with 32 maximum temperature events above $21^{\circ} \mathrm{C}$ and this is during the whole seed filling period) in 2011-12 season. Whereas in 2012-13 season, daily temperature ranged from $-11^{\circ} \mathrm{C}$ to $32^{\circ} \mathrm{C}$ (early growth stage), from $-12^{\circ} \mathrm{C}$ (26 minimum temperature events with below $0^{\circ} \mathrm{C}$ ) to $28^{\circ} \mathrm{C}$ (beginning of regrowth to beginning of flowering), from $-9^{\circ} \mathrm{C}\left(12\right.$ minimum temperature events with below $00^{\circ} \mathrm{C}$, flowering and podding stages) to $34^{\circ} \mathrm{C}$ (with 44 maximum temperature events above $21^{\circ} \mathrm{C}$ ), from $9^{\circ} \mathrm{C}$ to $39^{\circ} \mathrm{C}$ (with 30 maximum temperature events above $21^{\circ} \mathrm{C}$ during the whole seed filling period) in 2012-13 season. As seen with the above minimum temperature events, the 2012-13 season was a lot colder than the 2011-12 season during early growth, flowering and pod formation stages leading to longer time requirement for plants to reach those different stages including maturity (Table 1). The extreme and potentially yield limiting weather that occurred in 2012-13 season during flowering and early podding stages resulted in the loss of plant parts including flowers, buds and small pods. This, in turn, resulted in plants investing some of the resources for regrowth which otherwise could have been used for more pods and hence more seeds and possibly more yield.

\subsection{Crop Establishment and Plant Stand}

Canola establishment and subsequent fall plant stand density were good for all of the three planting dates (mid-September, late-September and early-October) in both 2011-12 and 2012-13 seasons. This was expected since the growing conditions including moisture through irrigation was favorable for the crop to establish well. Although the crop established well, as expected plants of late planting date were much smaller when winter arrived reflecting the shorter time and accumulated degree days resulting from the delay in planting. There was a significant year $\mathrm{x}$ planting date interaction effect $(p<0.0001)$ on fall plant stand density. The highest fall plant stand density was recorded for early-October $\left(133 \mathrm{plants} \cdot \mathrm{m}^{-2}\right)$ and mid-September (128 plants $\left.\cdot \mathrm{m}^{-2}\right)$ plantings in 2011-12 and mid-September planting in 2012-13 (127 plants $\left.\mathrm{m}^{-2}\right)$ seasons. Groups with second and third for fall 
Table 1. Fall and spring plant stand and their ratio of four canola varieties under three planting dates in 2011-12 and 2012-13 seasons.

\begin{tabular}{|c|c|c|c|c|c|}
\hline \multirow[b]{2}{*}{ Planting dates } & 2011-12 & 2012-13 & 2011-12 & $2012-13$ & \multirow{2}{*}{$\begin{array}{c}2 \text { yrs avg } \\
\text { Fall to spring plant stand ratic }\end{array}$} \\
\hline & \multicolumn{2}{|c|}{ Fall plant stand (numbers $\cdot \mathrm{m}^{-2}$ ) } & \multicolumn{2}{|c|}{ Spring plant stand (numbers $\cdot \mathrm{m}^{-2}$ ) } & \\
\hline Mid-Sept. & $105^{\mathrm{a}}$ & 127 & 92 & 109 & 1.19 \\
\hline Late-Sept. & 128 & 87 & 111 & 90 & 1.07 \\
\hline Early-Oct. & 133 & 115 & 102 & 102 & 1.25 \\
\hline $\operatorname{LSD}(0.05)$ & \multicolumn{2}{|c|}{10} & \multicolumn{2}{|c|}{12} & 0.10 \\
\hline DKW4110 & 119 & & 121 & 98 & \\
\hline DKW4615 & 129 & & 106 & 124 & \\
\hline RILEY & 102 & & 84 & 85 & \\
\hline WICHITA & 115 & & 95 & 95 & \\
\hline $\operatorname{LSD}(0.05)$ & 10 & & & & \\
\hline \multicolumn{6}{|l|}{ Source of variation } \\
\hline Year (Y) & 0.0208 & & 0.7943 & & 0.1239 \\
\hline Planting date (PD) & 0.0155 & & 0.9326 & & 0.0148 \\
\hline $\mathrm{Y} \times \mathrm{PD}$ & $<0.0001$ & & 0.0129 & & 0.0862 \\
\hline Variety (V) & 0.0008 & & $<0.0001$ & & 0.5430 \\
\hline $\mathrm{Y} \times \mathrm{V}$ & 0.0905 & & 0.0014 & & 0.1713 \\
\hline PD x V & 0.1857 & & 0.6893 & & 0.5943 \\
\hline$Y \times P D x V$ & 0.8347 & & 0.7765 & & 0.9305 \\
\hline
\end{tabular}

${ }^{\mathrm{a}}$ Number within row $\mathrm{x}$ column groups differing by the values less than the LSD value were not different according to LSD ( $p>0.05$ ).

plant stand density were early-October and early-September planting dates of 2012-13 and 2011-12 seasons, respectively (Table 1$)$. The lowest fall plant stand density $\left(87\right.$ plants $\left.\cdot \mathrm{m}^{-2}\right)$ was recorded for late-September planting date in 2012-13 seasons. Plants of the first two planting dates (especially mid-September) in both seasons were more vigorous than the early-October planting. This result in part agrees with the results of research on canola planted in October 15 in Kansas produced higher fall plant stand than mid-August, early-September, mid-September and late-September plantings in one of 2 years studies [15].

There were year and variety one-way significant effects on fall plant stand density. Greater fall plant stand density, averaged over planting dates and varieties, was recorded in 2011-12 (122 plants $\left.\cdot \mathrm{m}^{-2}\right)$ compared to the 2012-13 season (110 plants $\mathrm{m}^{-2}$ ) perhaps a reflection of the slightly conducive warmer temperature occurred in 2011-12 (mean daily temperature ranging from $11^{\circ} \mathrm{C}$ to $23^{\circ} \mathrm{C}$ ) than in the $2012-13$ season (mean daily temperature ranging from $5^{\circ} \mathrm{C}$ to $23^{\circ} \mathrm{C}$ ) (Figure 1). There was significant difference between canola varieties for fall plant stand density (Table 1). Early flowering/maturing DKW46-15 and DKW41-10 varieties gave 129 and 119 plants $\cdot \mathrm{m}^{-2}$, respectively, followed by Wichita with 115 plants $\cdot \mathrm{m}^{-2}$ and the lowest plant stand density recording was for Riley with 102 plants $\cdot \mathrm{m}^{-2}$ reflecting their genetic makeup with the early flowering/maturing variety in general producing more plant stand than the medium flowering/maturing ones.

Plots were also assessed for spring plant stand density, and a significant year x planting date interactions effect $(p<0.0129)$ was detected for this variable. Within the interaction effects in spring plant stand density, the highest spring plant stand was recorded for late-September planting of 2011-12 (111 plants $\left.\cdot \mathrm{m}^{-2}\right)$ and mid-September planting of 2012-13 (109 plants $\left.\mathrm{m}^{-2}\right)$ seasons, followed by a secondary group that included early-October planting of both seasons (102 plants $\mathrm{m}^{-2}$ ) and the lowest plant stand density was recorded for late-September planting of 2012-13 season (90 plants $\cdot \mathrm{m}^{-2}$ ). A ratio of fall to spring plant stand density which is a good indicator of winter survival was also assessed and only planting date had significant effect on this variable (Table 1). The reduction in plant stand density ratio was 19 and $25 \%$ for mid-September and early-October, respectively while 
that of the late-September planting date had only $7 \%$ reduction in plant stand density ratio. This, perhaps, suggests that plant sizes of late-September planting to be less damaged by winter kill than the mid-September (bigger plants) and early-October (small plants) planting dates. Planting too early could lead to large plants resulting in excessive water and nutrient use, while planting too late on the other hand could produce small plants that are prone to winter kills [15] [16]. Too big of a plant from early planting and too small of a plant from late planting suggests a requirement of an optimum planting date for appropriate stage and plant size for better winter survival by the canola crop. As with fall plant stand density, the highest spring plant stand density was recorded for early flowering/maturing DKW41-10 and DKW 46-15 varieties (111 plants $\mathrm{m}^{-2}$, averaged over varieties), followed by medium flowering/maturing Wichita and Riley varieties ( 90 plants $\cdot \mathrm{m}^{-2}$, averaged over varieties). Early flowering/maturing variety had higher spring plant stand density than the medium flowering/maturing varieties which was also seen in fall plant stand density perhaps reflecting their overall genetic difference. Even though there was a reduction in spring plant stand density due to planting dates reflected in the ratio ranging from 7 to $25 \%$, final spring plant stand recorded in this study are more than the spring optimum stand density (80 to 150 and 60 to 80 plants $\mathrm{m}^{-2}$, for fall and spring stand density) reported in Europe [26] reflecting the milder winter and growing conditions of Southwestern US compared to the one in Europe. A study done in Kansas showed that spring plant stands of canola were not different among the earlier planting dates (mid-August, late-August and early-September) while later planting dates (late-September and mid-October) despite having higher fall plant stand, plants did not survive the winter and hence zero spring plant stand which can be linked to the growing conditions of the study area which was also rainfed while our study was under irrigation [15].

Given canola's ability to compensate for lower plant densities by producing larger leaf area, enhanced branching and increased number of pods per plant, average yield can be achieved over a wide range of plant densities (8 - 90 plants $\mathrm{m}^{-2}$; [21]; 20 - 80 plants $\cdot \mathrm{m}^{-2}$; [34]). It was also reported that a plant stand density ranging from 34 to 64 plants $\mathrm{m}^{-2}$ (with similar seed yield 4800 and $4100 \mathrm{Kg} \cdot \mathrm{ha}^{-1}$ ) [5] for winter canola varieties planted from March through April in Australia. And these were considered as acceptable commercial levels (>30 plants $\mathrm{m}^{-2}$ ) to produce economical yield. Spring plant stand is more critical than fall plant stand density since yield is being determined by final spring plant stand not fall plant stand. Canola is also one of the crops reported to be capable of producing close to maximum yields with stand reductions by more than 50\% [35]. Since this was a study with irrigation, winter canola varieties tested here germinated and grew well in the fall and survived the winter well, and produced economical yield from all planting dates although there was a reduction in spring plant stand density.

\subsection{Crop Phenology}

There were a significant year x planting date and year $\mathrm{x}$ variety interaction effects on the time and degree days required for the plants to reach flower initiation, 50\% flowering, end of flowering, seed filling duration and maturation (Table 2 and Table 3). The number of days required for plants to reach flower initiation (174 to 187 vs. 184 to 195 days), 50\% flowering (179 to 192 vs. 191 to 204 days) and end of flowering (224 to 242 vs. 233 to 252 days) were significantly lower in the 2011-12 than in the 2012-13 seasons. The difference between the two seasons in number of days to reach these stages by the plants were also reflected in the accumulated GDD (for example 1153 to 1218 vs. 1259 to 1322 GDD were required to 50\% flowering , for 2011-12 and 2012-13 seasons, respectively, Table 3). Minimum temperatures during rosette and beginning of regrowth have been linked to prolonging plant stages including stem elongation and flower initiation in winter crops [13] [16] [19] [20] [36] [37]. Twelve minimum temperature events below $0^{\circ} \mathrm{C}$ during beginning of regrowth to beginning of flowering occurred in 2011-12 season while 26 minimum temperature events with below $0^{\circ} \mathrm{C}$ occurred in 2012-13 seasons (Figure 1). Number of days and accumulated GDD requirements for plants to initiate flowering, $50 \%$ flowering and end of flowering were significantly affected by planting date in both seasons (Table 2 and Table 3). The number of days required for the above mentioned plant stages were reduced with delay in planting (for example, 174 vs. 187 days for early-October and mid-September, respectively in 2011-12 season and 184 vs. 195 days in 2012-13 seasons were required for plants to reach 50\% flowering) while more degree days being accumulated with delayed planting (Table 2 and Table 3). The shortening of plant growth period such as reaching $50 \%$ flowering with delayed planting date has been reported before for many crops including canola, safflower, wheat [13] [16] [20] [38]) which can lead to the faster phenological development resulting from more accumulated growing degree days. 
Table 2. Growing degree days required from planting to start of flowering, 50\% flowering and end of flowering and seed filling duration of four canola varieties under three planting dates in 2011-12 and 2012-13 seasons.

\begin{tabular}{|c|c|c|c|c|c|c|c|c|}
\hline & 2011-12 & 2012-13 & 2011-12 & $2012-13$ & 2011-12 & $2012-13$ & 2011-12 & $2012-13$ \\
\hline & \multicolumn{2}{|c|}{ Start of flowering } & \multicolumn{2}{|c|}{$50 \%$ flowering } & \multicolumn{2}{|c|}{ End of flowering } & \multicolumn{2}{|c|}{ Seed filling duration } \\
\hline Planting dates & \multicolumn{8}{|c|}{ Growing degree days from planting } \\
\hline Mid-Sept. & $1080^{\mathrm{a}}$ & 1176 & 1153 & 1259 & 1933 & 2189 & 692 & 754 \\
\hline Late-Sept. & 1099 & 1210 & 1186 & 1290 & 1933 & 2191 & 692 & 753 \\
\hline Early-Oct. & 1158 & 1251 & 1218 & 1322 & 1933 & 2189 & 692 & 754 \\
\hline Mean & 1112 & 1212 & 1186 & 1290 & 1933 & 2190 & 692 & 754 \\
\hline LSD (0.05) & \multicolumn{2}{|c|}{6.2} & \multicolumn{2}{|c|}{6.2} & \multicolumn{2}{|c|}{1.3} & \multicolumn{2}{|c|}{1.3} \\
\hline DKW4110 & 1081 & 1183 & 1130 & 1240 & 1933 & 2191 & 692 & 753 \\
\hline DKW4615 & 1123 & 1230 & 1198 & 1297 & 1933 & 2189 & 692 & 753 \\
\hline RILEY & 1121 & 1210 & 1205 & 1302 & 1933 & 2189 & 692 & 753 \\
\hline WICHITA & 1124 & 1226 & 1209 & 1322 & 1933 & 2189 & 692 & 753 \\
\hline Mean & 1112 & 1212 & 1186 & 1290 & 1933 & 2190 & 692 & 753 \\
\hline LSD (0.05) & \multicolumn{2}{|c|}{5.9} & \multicolumn{2}{|c|}{5.8} & \multicolumn{2}{|c|}{1.4} & \multicolumn{2}{|c|}{1.4} \\
\hline \multicolumn{9}{|l|}{ Source of variation } \\
\hline Year (Y) & \multicolumn{2}{|l|}{$<0.0001$} & \multicolumn{2}{|l|}{$<0.0001$} & \multicolumn{2}{|l|}{$<0.0001$} & \multicolumn{2}{|l|}{$<0.0001$} \\
\hline Planting date (PD) & \multicolumn{2}{|l|}{$<0.0001$} & \multicolumn{2}{|l|}{$<0.0001$} & \multicolumn{2}{|l|}{0.3966} & \multicolumn{2}{|l|}{0.3966} \\
\hline$Y \times P D$ & \multicolumn{2}{|l|}{0.0403} & \multicolumn{2}{|l|}{0.9269} & \multicolumn{2}{|l|}{0.3966} & \multicolumn{2}{|l|}{0.3966} \\
\hline Variety (V) & \multicolumn{2}{|l|}{$<0.001$} & \multicolumn{2}{|l|}{$<0.0001$} & \multicolumn{2}{|l|}{0.4000} & \multicolumn{2}{|l|}{0.4000} \\
\hline $\mathrm{YxV}$ & \multicolumn{2}{|l|}{0.0383} & \multicolumn{2}{|l|}{0.0066} & \multicolumn{2}{|l|}{0.4000} & \multicolumn{2}{|l|}{0.4000} \\
\hline $\mathrm{PD} \times \mathrm{V}$ & 0.1659 & & $<0.0001$ & & 0.4350 & & 0.4350 & \\
\hline$Y \times P D \times V$ & 0.3709 & & 0.0770 & & 0.4350 & & 0.4350 & \\
\hline
\end{tabular}

${ }^{a}$ Number within row $x$ column groups differing by the values less than the LSD value were not different according to LSD ( $p>0.05$ ).

Table 3. Number of days required from planting to start of flowering, $50 \%$ flowering and end of flowering and seed filling duration of four canola varieties under three planting dates in 2011-12 and 2012-13 seasons.

\begin{tabular}{|c|c|c|c|c|c|c|c|c|}
\hline & 2011-12 & 2012-13 & 2011-12 & 2012-13 & 2011-12 & 2012-13 & 2011-12 & $2012-13$ \\
\hline & \multicolumn{2}{|c|}{ Start of Flowering } & \multicolumn{2}{|c|}{$50 \%$ flowering } & \multicolumn{2}{|c|}{ End of flowering } & \multicolumn{2}{|c|}{ Seed filling duration } \\
\hline Planting dates & \multicolumn{8}{|c|}{ Number of days from planting } \\
\hline Mid-Sept. & $187^{\mathrm{a}}$ & 195 & 192 & 204 & 242 & 252 & 31 & 32 \\
\hline Late-Sept. & 180 & 192 & 185 & 200 & 233 & 245 & 31 & 32 \\
\hline Early-Oct. & 174 & 184 & 179 & 191 & 224 & 233 & 31 & 32 \\
\hline Mean & 180 & 190 & 185 & 198 & 233 & 243 & 31 & 32 \\
\hline LSD (0.05) & \multicolumn{2}{|c|}{0.66} & \multicolumn{2}{|c|}{0.46} & \multicolumn{2}{|c|}{0.12} & \multicolumn{2}{|c|}{0.12} \\
\hline \multicolumn{9}{|l|}{ Variety } \\
\hline DKW4110 & 178 & 187 & 182 & 193 & 233 & 244 & 31 & 31 \\
\hline DKW4615 & 181 & 193 & 186 & 199 & 233 & 243 & 31 & 32 \\
\hline RILEY & 181 & 190 & 187 & 199 & 233 & 243 & 31 & 32 \\
\hline WICHITA & 181 & 192 & 187 & 201 & 233 & 243 & 31 & 32 \\
\hline Mean & 180 & 191 & 186 & 198 & 233 & 243 & 31 & 32 \\
\hline LSD (0.05) & \multicolumn{2}{|c|}{0.63} & \multicolumn{2}{|c|}{0.47} & \multicolumn{2}{|c|}{0.14} & \multicolumn{2}{|c|}{0.15} \\
\hline \multicolumn{9}{|l|}{ Source of variation } \\
\hline Year $(\mathrm{Y})$ & \multicolumn{2}{|l|}{$<0.0001$} & \multicolumn{2}{|l|}{$<0.0001$} & \multicolumn{2}{|l|}{$<0.0001$} & \multicolumn{2}{|l|}{$<0.0001$} \\
\hline Planting date (PD) & \multicolumn{2}{|l|}{$<0.0001$} & \multicolumn{2}{|l|}{$<0.0001$} & \multicolumn{2}{|l|}{$<0.0001$} & \multicolumn{2}{|l|}{0.3966} \\
\hline$Y \times P D$ & \multicolumn{2}{|l|}{0.0009} & \multicolumn{2}{|l|}{0.0270} & \multicolumn{2}{|l|}{$<0.0001$} & \multicolumn{2}{|l|}{0.3966} \\
\hline Variety (V) & \multicolumn{2}{|l|}{$<0.001$} & \multicolumn{2}{|l|}{$<0.0001$} & \multicolumn{2}{|l|}{$<0.0001$} & \multicolumn{2}{|l|}{$<0.0001$} \\
\hline $\mathrm{Yx} \mathrm{V}$ & \multicolumn{2}{|l|}{0.0006} & \multicolumn{2}{|l|}{$<0.0001$} & $<0.0001$ & & $<0.0001$ & \\
\hline PD x V & 0.4414 & & $<0.0001$ & & 0.7290 & & 0.7290 & \\
\hline$Y \times P D \times V$ & 0.0898 & & $<0.0001$ & & 0.7290 & & 0.7290 & \\
\hline
\end{tabular}

${ }^{\mathrm{a}}$ Number within row $\mathrm{x}$ column groups differing by the values less than the LSD value were not different according to LSD ( $p>0.05$ ). 
Averaged over years and varieties, pushing planting date from mid-September to early-October has shortened the time for $50 \%$ flowering by as many as 13 days which is about 0.7 day shortening for each day delay in planting (Table 3). The shortening of the time to 50\% flowering and hence vegetative and maturity period resulting from delay in planting in canola has been reported by many researchers before [13] [16] [19] [20]. The flowering duration, which can be calculated from Table 2, was reduced by 5 to 8 days with delay in planting (early-October vs. mid-September planting). On the other hand, seed filling period (from the time plants ended flowering to maturity, Table 3) was not affected by planting date in both 2011-12 and 2011-13 seasons (31 and 32 days were required for all planting dates in 2011-12 and 2012-13, respectively) which was also reflected in GDD requirements (692 and 754 GDD, for 2011-12 and 2012-13 seasons, respectively). Thus, shortening of the vegetative growth and the flowering periods are the ones that were most affected by delay in planting. This can result in reduced assimilate production and pod setting and consequently seed fill and final yield. In general, early flowering/maturing DKW41-10 variety in particular, did require fewer days to reach 50\% flowering than the medium flowering/maturing Riley and Wichita varieties in both 2011-12 and 2012-13 seasons reflected also in their greater accumulated GDD requirement (Table 2 and Table 3). This could be attributed to their difference in plant development and genetic makeup. Later maturing genotypes of crops have been reported to be more responsive to planting dates than early maturing variety resulting from their responsiveness to temperature and photoperiod [13] [38].

\subsection{Aboveground Dry Matter}

The effect of year and planting date on final aboveground dry matter were significant $(p=0.0257$ and $p<$ 0.0001 , respectively). Aboveground dry matter, averaged over planting date and varieties, produced in 2012-13 was significantly higher than the 2011-12 seasons (9745 vs. $8401 \mathrm{Kg} \cdot \mathrm{ha}^{-1}$ ) reflecting not only the favorable growing conditions created by supplemental irrigation especially during rapid growth and flowering periods but also in part to the prolonged overall growth/regrowth period due to lower temperatures that occurred during winter, early- and late spring (Figure 1). This was also reflected in the greater number of days and accumulated growing degree days requirement for plants to reach the different plant growth stages in 2012-13 than in the 2011-12 seasons (Table 2 and Table 4). Aboveground dry matter, averaged over varieties, of mid-September

Table 4. Aboveground dry matter, seed yield and oil yield and harvest index of four canola varieties under three planting dates in 2011-12 and 2012-13 seasons.

\begin{tabular}{|c|c|c|c|c|c|c|c|c|}
\hline & 2011-12 & 2012-13 & 2011-13 & 2012-13 & 2011-12 & 2012-13 & 2011-12 & 2012-13 \\
\hline & \multicolumn{2}{|c|}{ Seed yield } & \multicolumn{2}{|c|}{ Aboveground dry matter } & \multicolumn{2}{|c|}{ Oil yield } & \multicolumn{2}{|c|}{ Harvest index } \\
\hline Planting dates & \multicolumn{6}{|c|}{$\left(\mathrm{Kg} \cdot \mathrm{ha}^{-1}\right)$} & & \\
\hline Mid-Sept. & $2634^{\mathrm{a}}$ & 2603 & 9440 & 10795 & 980 & 965 & 0.28 & 0.23 \\
\hline Late-Sept. & 2174 & 2593 & 8281 & 9915 & 814 & 980 & 0.26 & 0.25 \\
\hline Early-Oct. & 1944 & 2388 & 7499 & 8541 & 745 & 903 & 0.25 & 0.27 \\
\hline LSD (0.05) & \multicolumn{2}{|c|}{272} & \multicolumn{2}{|c|}{525} & \multicolumn{2}{|c|}{525} & \multicolumn{2}{|c|}{0.01} \\
\hline DKW4110 & 1438 & 2124 & 7280 & 9461 & 522 & 758 & 0.20 & 0.22 \\
\hline DKW4615 & 2167 & 2417 & 7579 & 9306 & 843 & 946 & 0.28 & 0.25 \\
\hline RILEY & 2805 & 2838 & 9534 & 10271 & 1052 & 1076 & 0.29 & 0.26 \\
\hline WICHITA & 2593 & 2732 & 9210 & 9940 & 970 & 1018 & 0.28 & 0.26 \\
\hline LSD (0.05) & \multicolumn{2}{|c|}{276} & \multicolumn{2}{|c|}{1108} & \multicolumn{2}{|c|}{108} & \multicolumn{2}{|c|}{0.02} \\
\hline \multicolumn{9}{|l|}{ Source of variation } \\
\hline Year (Y) & \multicolumn{2}{|l|}{0.1452} & \multicolumn{2}{|l|}{0.0257} & \multicolumn{2}{|l|}{$<0.2042$} & \multicolumn{2}{|l|}{0.1120} \\
\hline Planting date (PD) & \multicolumn{2}{|l|}{$<0.0007$} & \multicolumn{2}{|l|}{$<0.0001$} & \multicolumn{2}{|l|}{$<0.0014$} & \multicolumn{2}{|l|}{0.1406} \\
\hline $\mathrm{Y} \times \mathrm{PD}$ & \multicolumn{2}{|l|}{0.0271} & \multicolumn{2}{|l|}{0.4662} & \multicolumn{2}{|l|}{$<0.0184$} & \multicolumn{2}{|l|}{$<0.0001$} \\
\hline Variety (V) & \multicolumn{2}{|l|}{$<0.001$} & \multicolumn{2}{|l|}{$<0.0001$} & \multicolumn{2}{|l|}{$<0.0001$} & \multicolumn{2}{|l|}{$<0.0001$} \\
\hline $\mathrm{Y} \times \mathrm{V}$ & \multicolumn{2}{|l|}{0.0070} & \multicolumn{2}{|l|}{$<0.0055$} & \multicolumn{2}{|l|}{$<0.0256$} & \multicolumn{2}{|l|}{$<0.0001$} \\
\hline $\mathrm{PD} \times \mathrm{V}$ & \multicolumn{2}{|l|}{0.7948} & $<0.8098$ & & 0.7228 & & 0.2225 & \\
\hline$Y \times P D \times V$ & 0.6165 & & $<0.9172$ & & 0.4596 & & 0.0825 & \\
\hline
\end{tabular}

${ }^{a}$ Number within row x column groups differing by the values less than the LSD value were not different according to LSD ( $p>0.05$ ). 
planting was significantly greater than late-September and early-October planting dates in both 2011-12 and 2012-13 growing seasons (Table 4). There was a negative relationships between planting date and aboveground dry matter at both 50\% flowering and final harvest (Figure 2 and Figure 4) reflecting the shortening of the vegetative growth periods, accounting for 92\% (2012-13 season at 50\% flowering), 81\% (2012-13 season at final harvest)and 39\% ((2011-12 season at final harvest) variation . For example, days to 50\% flowering was shortened by as many as 13 days when planting was moved from mid-September to early-October (Table 3) with more accumulated growing degree days for later planting date than early planting date as seen in Table 2 which, in turn, can result in the overall rapid development of the crop. A decline in aboveground dry matter due to delay in planting has been reported by many researchers before for oilseed crops such as canola, mustard, safflower [9] [10] [13] [16] [19] [20] [38] and cereal crops [11] [14]. Furthermore, results of the above mentioned researchers did show a strong positive relationships between aboveground dry matter and seed yield in relation to planting dates; a decline in seed yield due to delay in planting date being largely explained by the decline in final aboveground dry matter due to the shortening of vegetative growth period as seen in this study as well (Table 3).
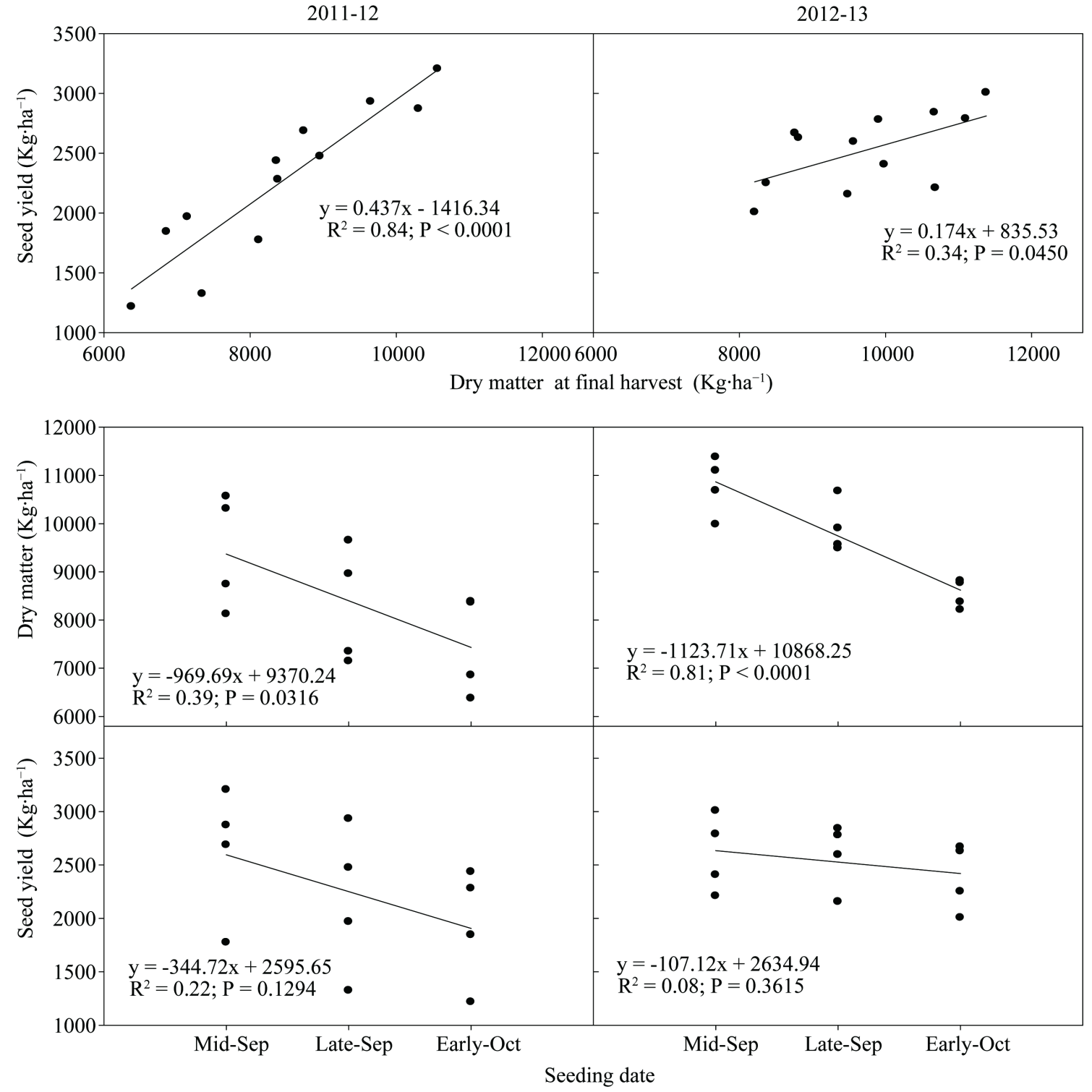

Figure 2. Relationships between dry matter, seed yield and planting date at final harvest for 3 planting dates and 4 varieties in 2011-12 and 2012-13 seasons. 
Significant year $\mathrm{x}$ variety interactions $(p<0.0055)$ in aboveground dry matter were detected. In both 2011-12 and 2012-13 seasons, aboveground dry matter at final harvest by medium flowering/maturing varieties Riley and Wichita (ranging from 9210 to $10271 \mathrm{Kg} \cdot \mathrm{ha}^{-1}$ ) was higher than the early flowering/maturing varieties DKW4110 and DKW46-15 (7280 to $9461 \mathrm{Kg} \cdot \mathrm{ha}^{-1}$ ) although the degree of difference between maturity groups was more pronounced for 2011-12 (21\%) than the 2012-13 (7\%) seasons (Table 4). The higher aboveground dry matter by medium flowering/maturing varieties than the early flowering/maturing canola varieties was expected since this can be related to the difference in their overall genetic makeup difference. With all growth affecting factors being unlimiting, differences among canola varieties for time to flowering and maturity; and dry matter production and yield can be linked to their differences in both genetics and phenological development [13]. Aboveground dry matter of the early maturing varieties (DKW44-10 and DKW46-15) was significantly higher in 2012-13 than the 2011-12 season whereas the difference between the two seasons for this same variable for the medium flowering/maturing verities (Riley and Wichita) was only arithmetical (Table 4). The many days of cooler and freezing temperatures plants experienced during early and late spring (Figure 1) resulted in plant parts being killed including flowers and small pods, perhaps more so in early- than medium flowering, leading to more regrowth by the early than the medium flowering varieties. Moreover, the favorable moisture conditions created with the extra supplemental irrigation, in April and May in particular $(273.1 \mathrm{~mm}$ vs. $210 \mathrm{~mm}$, for the 2012-13 and 2011-12 seasons, respectively resulted in more regrowth and hence greater final dry matter production in 2012-13 than in 2011-12 season, especially for early flowering than medium flowering varieties.

Regardless of the planting dates, all varieties produced more than $5000 \mathrm{Kg}^{-h^{-1}}$ aboveground dry matter at flowering (Figure 3) as recorded in 2012-13 season and more than $7000 \mathrm{Kg} \cdot \mathrm{ha}^{-1}$ aboveground dry matter at maturity in both 2011-12 and 2012-13 seasons (Table 4) to be maximum enough for maximum yield under the growing conditions of the region. Several studies have suggested a biomass of $5000 \mathrm{Kg} \cdot \mathrm{ha}^{-1}$ at flowering to be maximum enough for maximum yield with little yield advantage for crops with higher levels of biomass [21]
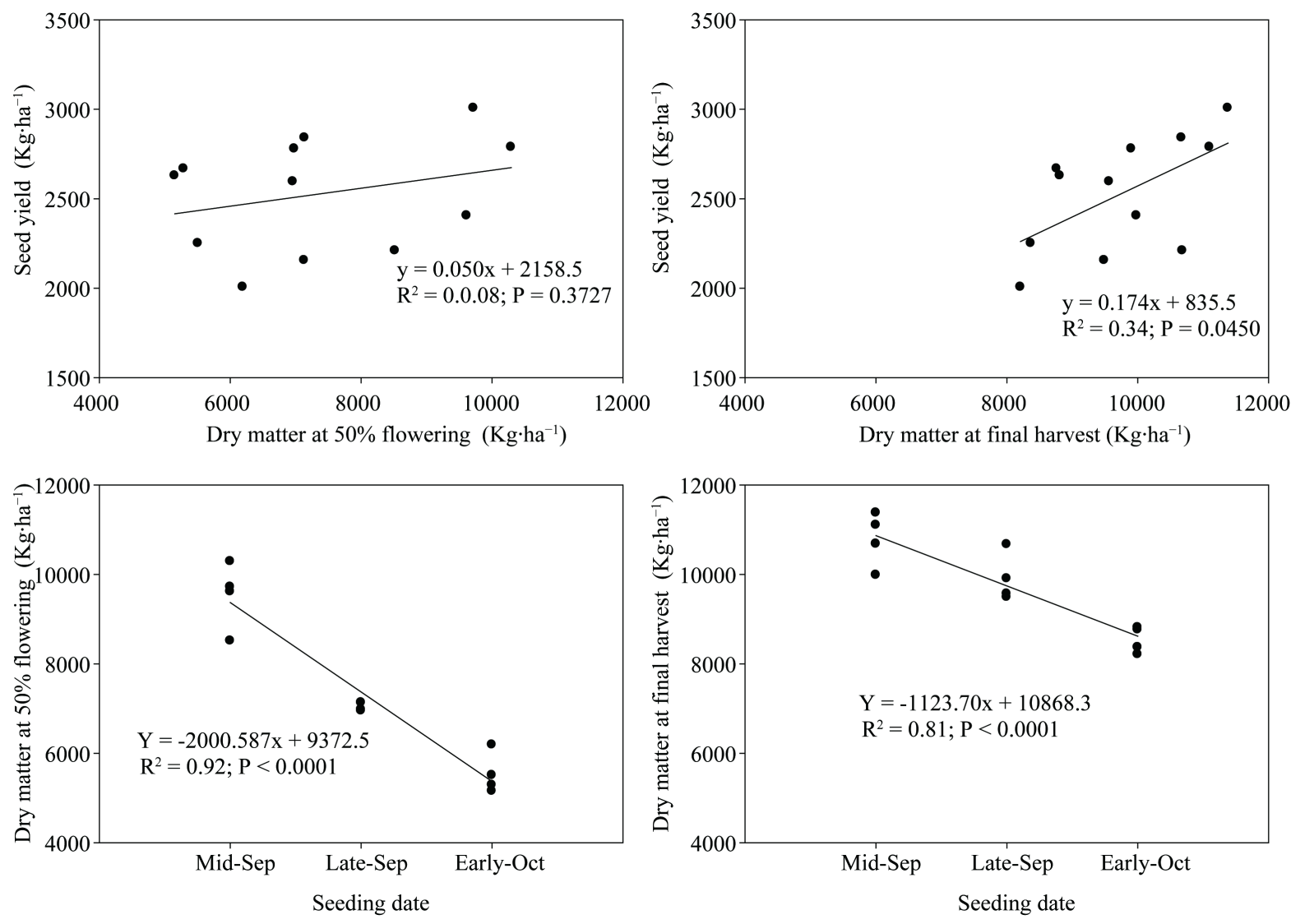

Figure 3. Relationships between dry matter, seed yield and planting date at flowering and final harvest for 3 planting dates and 4 varieties in 2012-13 season. 
[22]. In the other hand, research done in Australia [23] showed that an increase in seed yield with an increase in biomass at flowering and maturity although this was dependent on moisture conditions. The above ground dry matter production level achieved in our study is in agreement with the result of research done in Australia [23] a higher seed yield with an increase in dry matter production beyond the $5000 \mathrm{Kg} \cdot \mathrm{ha}^{-1}$ dry matter.

\subsection{Seed Yield and Harvest Index}

Year x planting date interaction effects was significant on seed yield ( $p<0.0271)$. Within the interaction effects in seed yield, the highest seed yield was recorded from mid-September ( $2634 \mathrm{Kg} \cdot \mathrm{ha}^{-1}$ ) compared to late-September (2174 Kg·ha ${ }^{-1}$ ) and early-October (1944 Kg·ha ${ }^{-1}$ ) plantings in 2011-12 season. However, the three planting dates were not significantly different for seed yield in 2012-13 and from that of the mid-September planting of 2011-12 season although there was a trend for a decline in seed yield with delay in planting, especially if planting is moved to early-October (8\% reduction in seed yield, Table 4) in the 2012-13 season. Seed yield, averaged over planting dates, of 2012-13 season was greater than seed yield of 2011-12 season (by 11\%). This reflects not only the favorable growing conditions created by supplemental irrigation especially during rapid growth and flowering (April and May combined) and seed filling in 2011-12 season (210 and 0 mm) were lower than that of the 2012-13 (273 and $57 \mathrm{~mm}$, respectively) seasons but also in part to the prolonged overall growth period resulting from lower temperatures occurred during winter, early- and late-spring (Figure 1 and Table 3) leading to higher aboveground dry matter production in 2012-13 than in the 2011-12 seasons (Table 4). Rainfall received during April through June was greater in 2011-12 (102 mm) than in the 2012-13 (64 mm) season but its timing of being coincided with the stages mentioned above was not as favorable as the supplemental irrigation given in 2012-13 season. The reduction in canola seed yield due to delay in planting found in our study is in agreement with values reported by several researchers ranging from $3 \%$ to $20 \%$ encompassing the diverse growing conditions of Australia, China, Iran and USA [13] [15] [16] [19] [20].

The greater aboveground dry matter produced in 2012-13 than in the 2011-12 season was also the reflection of the lengthening of the growth period due to lower temperature; and the favorable moisture conditions created by the supplemental irrigation in 2012-13 season. However, this was not translated into higher harvest index in 2012-13 when it is compared with the 2011-12 season as shown in Figure 3 with a negative relationship between dry matter and harvest index while the opposite occurred in 2011-12 season. This was, perhaps, in part to plants being severely damaged by the early and late spring repeated freeze resulting in flowers, buds and initial pods being lost leading plants to invest more assimilates to vegetative regrowth than to pod formation and pod filling reflected in the lower harvest index of the 2012-13 compared to the 2011-12 seasons (Table 4 and Figure 4). Furthermore, the greater aboveground dry matter like the one noticed in 2012-13 season includes dead plant parts resulting from freeze damages but had little contribution in terms of assimilates use for seed-filling to make seed yield and harvest index of mid-September planting to be greater than that of the late-September and early-October planting dates (Figure 3). A weaker efficiency of biomass partitioning to seed (harvest index) for early planting canola under irrigated conditions in a research done in Australia had been noted [10] and this was linked to frost occurrence during flowering and early pod-filling period. Nevertheless, there was a positive relationship between aboveground dry matter at final harvest and canola seed yield, accounting for $84 \%$ and 34\% variation for 2011-12 and 2012-13 seasons, respectively indicating that aboveground dry matter can be used as a direct selection criterion for seed yield in variety selection and appropriate planting dates (Figure 2). This study is in agreement with what is well established in the literature [9]-[11] [13] [14] [16] [19] [20] [38] [39] indicating the strong positive relationship between dry matter (at flowering and maturity) and seed yield of diverse crops.

Year $\mathrm{x}$ variety interaction effects was significant in seed yield ( $p<0.007)$. Within the interaction effects in seed yield, the highest seed yield was produced by the medium flowering/maturing variety Riley $\left(2838 \mathrm{Kg} \cdot \mathrm{ha}^{-1}\right)$, followed by Wichita (2732 Kg·ha ${ }^{-1}$ ) and the least seed yield was produced by the early flowering/maturing variety DKW 44-10 (1438 Kg·ha ${ }^{-1}$ ) (Table 4) reflecting the aboveground dry matter production of the two maturity groups. The medium flowering/maturing varieties producing greater dry matter resulting in greater seed yield compared to early flowering/maturing varieties. Similar relationship between biomass production at maturity and seed yield has been reported before for canola cultivars grown across a wide range of environments in Australia [13]. Seed yields of all varieties were higher in 2012-13 than the 2011-12 growing season reflecting the higher aboveground matter production and overall lengthening of the growth periods and favorable growing 

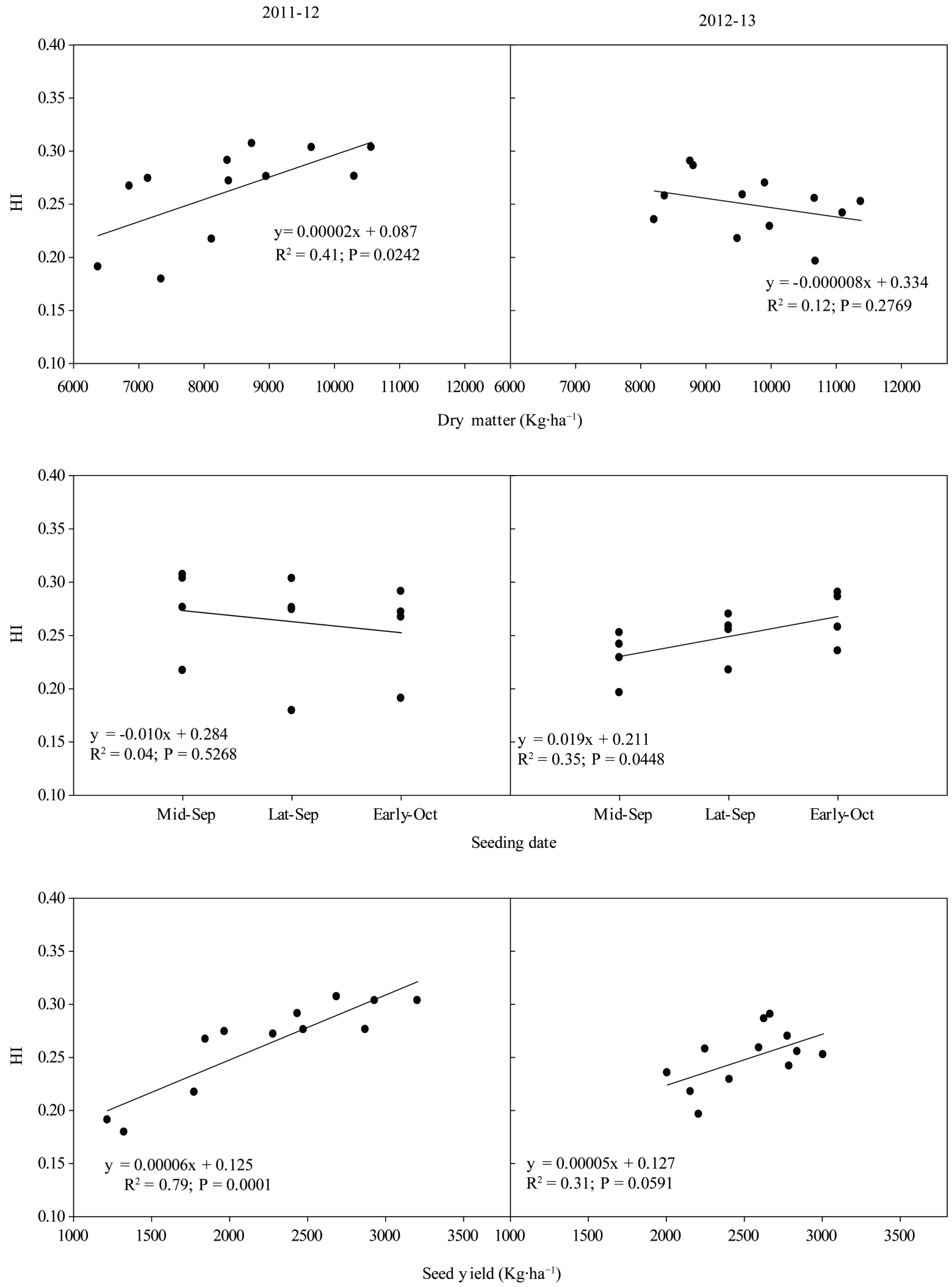

Figure 4. Relationships between harvest index, dry matter, planting date and seed yield at final harvest for 3 planting dates and 4 varieties in 2011-12 and 2012-13 seasons. 
conditions occurrence, supplemental irrigation in particular, in the 2012-13 season (Table 2 and Table 3). However, the early flowering/maturing varieties (DKW41-10 variety, in particular) produced significantly more seed yield in 2012-13 than in 2011-12 season compared to the medium flowering/maturing varieties and this was despite the medium maturing variety producing greater aboveground dry matter (Table 4). The medium maturing variety seemed to divert more resources to vegetative growth thereby, perhaps, reducing the availability of assimilates to seed-filling or/and seed filling-duration being not long enough to use assimilates so that the seed yield of the 2012-13 season was greater than that of the 2011-12 season. This was also reflected in the harvest index with higher values for early flowering/maturing variety DKW44-10 than the medium maturing for the 2012-13 than the 2011-12 growing seasons. Research done in Australia showed that no difference between the two canola varieties they tested (despite one variety being early and the other being later maturing) for harvest index suggesting harvest index being stable [13].

Seed oil content of varieties Riley and Wichita ranged from 36.6\% (mid-September planting) to 38.3\% (early-October planting) but no difference between these varieties was detected for seed oil content reflecting their similar phenological development and response to different planting dates. In the other hand, seed oil content of early flowering/maturing varieties were unaffected by planting dates (data not shown). Nevertheless, the varieties with highest harvest index had higher seed oil content. It was also suggested that conditions that are favorable to high assimilate supply during seed filling (as measured by high harvest index and large seed size) tend to be positively associated with high oil content [13]. Given the seed oil content difference recorded between the planting dates generally being too small $(<2 \%)$ their influence on final oil yield is minimal (Table 4$)$. The economy of winter oilseed rape cultivation is determined primarily by the achievable seed yield and less by oil content [23]. Oil yield, seed yield multiplied by seed oil content, did reflect seed yield's response to year and planting dates factors not seed oil content response's to the factors mentioned earlier.

\section{Conclusion}

Canola established and grew well under all planting dates (mid-September, late-September and early-October) reflected in fall and spring plant stand density in both seasons. However, when a ratio of fall to spring plant stand density was compared which was a good indicator of winter survival; a greater reduction in spring plant stand density occurred with early-October and mid-September than the late-September plantings. Delay in planting resulted in the shortening of the vegetative and flowering duration. The shorting of the vegetative duration was the main cause for the decline in above ground dry matter production leading to lower seed yield with delayed planting. The decline in aboveground dry matter (DM) due to delayed planting resulted in significant seed yield reduction and more so in 2011-12 (26\%) than in the 2012-13 (8\%) when early-October and mid-September plantings were compared. There was a positive relationship between DM at final harvest and canola seed yield, accounting for $84 \%$ and $34 \%$ variation for the 2 seasons, respectively; with the environmental conditions of 2011-12 season allowing the genetically controlled variation in DM production to become more apparent and strong in explaining the variation in seed yield among the varieties. Medium-flowering varieties produced higher aboveground dry matter and seed yield than early-flowering varieties. In addition to seed yield, DM could be used as an indirect selection criterion for seed yield in variety selection and appropriate planting dates including a guarantee for high crop residues ( $75 \%$ of the total aboveground biomass) production to make canola a potential alternative cash and rotational break crop in the Southwestern U.S.

\section{Acknowledgements}

We are thankful to USDA-NIFA-Supplemental and Alternative Crops Program (\#2010-38624-21709) and Agricultural Experiment Station of New Mexico State University for financial assistance. Technical assistance by Aaron Scott, Maria Nunez, Eldon Hays, Miguel Nunez, David Rodriquez Jose and Steve Brumfield is greatly appreciated.

\section{References}

[1] United States Department of Agriculture (USDA) Economic Research Service. 20113. http://www.ers.usda.gov/publications/ocs-oil-crops-outlook

[2] (FAO) Food and Agriculture Organization of the United Nations (2014) Global Information and Early Warning System 
on Food and Agriculture (GIEWS). Food Outlook, Rome, 186. http://www.fao.org/giews/english/fo/index.htm

[3] United States Department of Agriculture (USDA) Economic Research Service. 20113. Oil Crops Yearbook. http://www.ers.usda.gov/publications/ocs-oil-crops-outlook/ocs-13c

[4] Harris, R.H., Scammell, G.J., Muller, W.J. and Angus, J.F. (2002) Crop Production in Relation to Species of Previous Crops and Management of Previous Pasture. Australian Journal of Agricultural Research, 53, 1271-1283. http://dx.doi.org/10.1071/AR02021

[5] Kirkegaard, J.A., Sprague , S.J., Dove, H., Kelman, W.M., Marcroft, S.J., Lieschke, A., Howe, G.N., and Graham, J.M. (2008). Dual-Purpose Canola. A New Opportunity in Mixed Farming Systems. Australian Journal of Agricultural Research, 59, 291-302. http://www.publish.csiro.au/paper/AR07285.htm http://dx.doi.org/10.1071/AR07285

[6] Kirkegaard, J.A., Sprague, S.J., Dove, H., Potter, T.D., Marcroft, S.J, Kelman, W.M., Lilley, J.M. and Hamblin, P.J. (2010) Adaptation of Winter Canola. (Brassica napus) for Grain and Dual-Purpose Use in Australia's High Rainfall Zone. 15th Australian Agronomy Conference, Christchurch, New Zealand. http://www.regional.org.au/au/asa/2010/crop-production/dual-purpose

[7] Schillinger, W.F., Young, D.L., Kennedy, A.C. and Paulitz, T.C. (2010) Diverse No-Till Irrigated Croprotations Instead of Burning and Plowing Continuous Wheat. Field Crops Research, 115, 39-49.

http://dx.doi.org/10.1016/j.fcr.2009.10.001

[8] Boyles, M., Bushong, J., Sanders, H. and Stamm, M. (2012) Great Plains Canola Production Handbook. Kansas State University, MF2734. June 2012. http://www.bookstore.ksre.ksu.edu/pubs/mf2734.pdf

[9] Wright, G.C., Smith, C.J. and Woodroofe, M.R. (1988) The Effect of Irrigation and Nitrogen Fertilizer Onrapeseed (Brassica napus) Production in South-Eastern. Australian Irrigation Science, 9, 1-13. http://dx.doi.org/10.1007/BF00292139

[10] Taylor, A.J. and Smith, C.J. (1992) Effect of Sowing Date and Seeding Rate on Yield and Yield Components of Irrigated Canola (Brassica napus L.) Grown on a Red-Brown Earth in South-Eastern Australia. Australian Journal of Agricultural Research, 43, 1629-1641. http://www.publish.csiro.au/paper/AR9921629.htm http://dx.doi.org/10.1071/AR9921629

[11] Campbell, C.A., Selles, F., Zentner, R.P., Mcl-Eod, J.G. and Dyck, F.B. (1991) Effect of Seeding Date, Rate and Depth on Winter Wheat Grown on Conventional Fallow in S.W. Saskatchewan. Canadian Journal of Plant Science, 71, 5161. http://pubs.aic.ca/doi/abs/10.4141/cjps91-006 http://dx.doi.org/10.4141/cjps91-006

[12] Johnson, E.N., Miller, P.R., Blackshaw, R.E., Gan, Y., Harker, K.N., Clayton, G.W., Kephart, K.D., Wichman, D.M., Topinka, K. and Kirkland, K.J. (2004) Seeding Date and Polymer Seed Coating Effects on Plant Establishment and Yield of Fall-Seeded Canola in the Northern Great Plains. Canadian Journal of Plant Science, 84, 955-963.

http://pubs.aic.ca/doi/abs/10.4141/P04-005 http://dx.doi.org/10.4141/P04-005

[13] Robertson, M.J., Holland, J.F. and Bambach, R. (2004) Response of Canola and Indian Mustard to Sowing Date in the Grain Belt of North-Eastern Australia. Australian Journal of Experimental Agriculture, 44, 43-52.

http://www.regional.org.au/au/gcirc/2/483.htm http://dx.doi.org/10.1071/EA02214

[14] McKenzie, R.H., Bremer, E., Middleton, A.B., Pfiffner, P.G. and Woods, S.A. (2011) Optimum Seeding Date and Rate for Irrigated Cereal and Oilseed Crops in Southern Alberta. Canadian Journal of Plant Science, 91, 293-303. http://pubs.aic.ca/doi/abs/10.4141/CJPS10103 http://dx.doi.org/10.4141/CJPS10103

[15] Holman, J., Maxwell, S., Stamm, M. and Martin, K. (2011) Effects of Planting Date and Tillage on Winter Canola. https://dl.sciencesocieties.org/publications/cm/pdfs

[16] Wang, S., Wang, E., Wang, F. and Tang, L. (2012) Phenological Development and Grain Yield of Canola as Affected by Sowing Date and Climate Variation in the Yangtze River Basin of China. Crop \& Pasture Science, 63, 478-488. http://www.publish.csiro.au/paper/CP11332.htm http://dx.doi.org/10.1071/CP11332

[17] Stamm, M. and Dooley, S. (2013) Kansas State University, SRP1098. 2013 National Winter Canola Variety Trial. http://www.k-state.edu/historicpublications/pubs/SRP1098.pdf

[18] Miller, P., Lanier, W. and Brandt, S. (2001) Using Growing Degree Days to Predict Plant Stages. Montana State University. MT200103 AG 7/2001. http://store.msuextension.org/publications/AgandNaturalResources/MT200103AG.pdf

[19] Farre, I., Robertson, M.J., Walton, G.H. and Asseng, S. (2002) Simulating Phenology and Yield Response of Canola to Sowing Date in Western Australia Using the APSIM Model. Australian Journal of Agricultural Research, 53, 1155- 
1164. http://www.publish.csiro.au/?paper=AR02031 http://dx.doi.org/10.1071/AR02031

[20] Faraji, A.A., Latifi, N., Soltani, A. and Shiranirad, A.H. (2009) Seed Yield and Water Use Efficiency of Canola (Brassica napus) as Affected by High Temperature Stress and Supplemental Irrigation. Agricultural Water Management, 96, 132-140. http://www.sciencedirect.com/science/article/pii/S0378377408001790 http://dx.doi.org/10.1016/j.agwat.2008.07.014

[21] Mendham, N.J., Shipway, P.A. and Scott, R.K. (1981) The Effect of Delayed Sowing and Weather on Growth, Development and Yield of Winter Oilseed Rape (Brassica napus). Journal of Agricultural Science, 96, 389-416. http://dx.doi.org/10.1017/S002185960006617X

[22] McCormick, J.I., Virgona, J.M. and Kirkegaard, J.A. (2012) Growth and Yield of Dual Purpose Canola (Brassica napus) under Drier Inland Seasonal Conditions of South-Eastern Australia. Crop Pasture Science, 63, 635-646. http://www.publish.csiro.au/?act=view_file\&file_id=CP12078.pdf http://dx.doi.org/10.1071/CP12078

[23] Raffkin, P., Potter, T. and Kearney, G. (2012) Yield Performance of Late-Maturing Winter Canola (Brassica napus L.) Types in the High Rain Fall Zone of Southern Australia. Crop Pasture Science, 63, 17-32. http://www.publish.csiro.au/?act=view_file\&file_id=CP10410.pdf http://dx.doi.org/10.1071/CP10410

[24] Bishnoi, R.U., Suresh, K., Ernest, C. and Rao, S.M. (2007) Agronomic and Economic Performance of Winter Canola in Southeastern US. World Journal of Agricultural Sciences, 3, 263-268. http://www.idosi.org/wjas/wjas3(3)/1.pdf

[25] Rathke, G.W., Behrens, T. and Diepenbrock, W. (2006) Integrated Nitrogen Management Strategies to Improve Seed Yield, Oil Content and Nitrogen Efficiency of Winter Oilseed Rape (Brassica napus L.): A Review. Agriculture Ecosystems and Environment, 117, 80-108. http://www.sciencedirect.com/science/article/pii/S0167880906001472 http://dx.doi.org/10.1016/j.agee.2006.04.006

[26] Diepenbrock, W. and Grosse, F. (1995) Rapeseed-Physiology. In: Diepenbrock, W. and Becker, H.C., Eds., Physiological Potentials for Yield Improvement of Annual Oil and Protein Crops, Blackwell Science, Berlin and Vienna, 21-53.

[27] Diepenbrock, W. (2000) Yield Analysis of Winter Oilseed Rape (Brassica napus L.): A Review. Field Crops Research, 67, 35-49. http://dx.doi.org/10.1016/S0378-4290(00)00082-4

[28] Harper, F. and Compton, I.J. (1980) Sowing Date, Harvest Date and the Yield of Forage Brassica Crops. Grass and Forage Science, 35, 147-157. http://dx.doi.org/10.1111/j.1365-2494.1980.tb01504.x

[29] Angadi, S.V., Cutforth, H.W., Miller, P.R., McConkey, B.G., Entz, M.H., Brandt, S.A. and Volkmar, K.M. (2000) Response of Three Brassica Species to High Temperature Stress during Reproductive Growth. Canadian Journal of Plant Science, 80, 693-701. http://pubs.aic.ca/doi/pdf/10.4141/P99-152 http://dx.doi.org/10.4141/P99-152

[30] Sidlauskas, G. and Bernotas, S. (2003) Some Factors Affecting Seed Yield of Spring Oilseed Rape (Brassica napus L.). Agronomy Research, 1, 229-243. http://agronomy.emu.ee/vol012/Sidlauskas.pdf

[31] Brandt, S.A., Malhi, S.S., Ulrich, D., Lafond, G.P., Kutcher, H.R. and Johnston, A.M. (2007) Seeding Rate, Fertilizer Level and Disease Management Effects on Hybrid versus Open Pollinated Canola (Brassica napus L.). Canadian Journal of Plant Science, 87, 255-266. http://pubs.aic.ca/doi/pdf/10.4141/P05-223 http://dx.doi.org/10.4141/P05-223

[32] SAS Inst. (2007) The SAS System for Windows. Release 9.1.3 SAS Inst. Inc., Cary.

[33] Littell, R.C., Stroup, W.W. and Freund, R.J. (2002) SAS for Linear Models. 4th Edition, SAS Inst. Inc., Cary, 466 p.

[34] Angadi, S.V., Cutforth, H.W., McConkey, B.G. and Gan, Y. (2003) Yield Adjustment by Canola Grown at Different Plant Populations under Semiarid Conditions. Crop Science, 43, 1358-1366.

http://dx.doi.org/10.2135/cropsci2003.1358

https://dl.sciencesocieties.org/publications/cs/articles/43/4/1358

[35] OMAFRA (2011) Spring and Winter Canola: Fertility Management. In: Agronomy Guide for Field Crops, Pub. 811. Ontario Ministry of Agriculture, Food and Rural Affairs. http://www.omafra.gov.on.ca/english/crops/pub811/6fertility.htm

[36] Zimmerman, L.H. (1973) Effect of Photoperiod and Temperature on Rosette Habit in Safflower. Crop Science, 13, 8081. http://dx.doi.org/10.2135/cropsci1973.0011183X001300010024x

[37] Abel, G.H. (1976) Effects of Irrigation Regimes, Planting Dates, Nitrogen Levels, and Row Spacing on Safflower Cultivars. Agronomy Journal, 68, 448-451. http://dx.doi.org/10.2134/agronj1976.00021962006800030003x

[38] Koutroubas, S.D., Papakosta, D.K. and Doitsinis, A. (2004) Cultivar and Seasonal Effects on the Contribution of PreAnthesis Assimilates to Safflower Yield. Field Crops Research, 90, 263-274. 
http://www.sciencedirect.com/science/article/pii/S0378429004001224 http://dx.doi.org/10.1016/j.fcr.2004.03.009

[39] Specht, J.E., Williams, J.H. and Weidenbenner, C.J. (1986) Differential Responses of Soybean Genotypes Subjected to a Seasonal Soil Water Gradient. Crop Science, 26, 922-934.

http://dx.doi.org/10.2135/cropsci1986.0011183X002600050018x

https://dl.sciencesocieties.org/publications/cs/abstracts/26/5/CS0260050922 